\title{
ESCOLAS DE FORMAÇÃO DE PROFESSORES/AS NO BRASIL E EM PORTUGAL E A FEMINIZAÇÃO DO MAGISTÉRIO
}

\author{
Amanda Rabelo \\ Universidade Federal Fluminense
}

\begin{abstract}
RESUMO
Este artigo apresenta um histórico desde o período da colonização do Brasil por Portugal até os dias atuais da institucionalização das escolas de formação de professores/as e da sua relação com a feminização do magistério primário. Apresentaremos um esboço de algumas abordagens teóricas sobre história da educação, elegendo bibliografias de ambos os países que fizessem análises históricas com escolhas documentais alargadas e/ou diferenciadas, que deram ênfase também à análise das narrativas e dos discursos, bem como buscamos algumas fontes oficiais e dados estatísticos. Deste processo concluimos que esta é uma história de luta feminina entre discursos favoráveis e negativos à sua entrada nos cursos de formação para o magistério, de crescimento do número de mulheres e de saída dos homens dos cursos de formação, de valorização da condição feminina e do status da profissão, de abertura profissional às mulheres, entre outros aspectos que desenvolveremos no decorrer do artigo.

Palavras-chave: escolas normais; formação de professores; feminização do magistério; estudo comparado.
\end{abstract}

\section{TEACHER TRAINING SCHOOLS IN BRAZIL AND IN PORTUGAL AND THE TEACHING FEMINIZATION}

\begin{abstract}
This article presents a history from the period of colonization of Brazil by Portugal to the present day about the institutionalization of teacher training schools and its relation to primary teaching feminization. This paper present an outline of some theoretical approaches about education history, electing bibliographies of both countries that make historical analysis with extensive documentary or differentiated, which also emphasized the narratives and discourses analysis, and seek some official sources and statistical data. In this case, we conclude that this is a history of women's struggle between negative and favorable discourses to its entry into the teaching training courses, growth in women number and men output in courses, of feminine condition recovery and status of the profession, professional open to women, and other aspects that develop throughout the article.
\end{abstract}

Keywords: teacher training schools, teacher training, teaching feminization, study compared.

\section{Introdução}

Realizaremos um histórico desde o período da colonização do Brasil por Portugal até os dias atuais da institucionalização das escolas de formação de professores/as e da sua relação com a feminização do magistério primário. Apesar de visar os estudos genealógicos, não temos a pretensão de traçar uma genealogia no sentido estrito, desejamos apenas apresentar um esboço de algumas abordagens teóricas sobre história da educação (as bibliografias já produzidas sobre o assunto) que nos apóiam na nossa busca. Assim, ao invés de localizarmos uma essência para os acontecimentos, preferimos diagnosticar os discursos que circulavam e a preponderância de algumas representações sobre outras.

Não podemos nos esquecer que os estudos comparados não podem limitar-se a constatar o que ocorre em cada país: é preciso efetuar uma história de sentidos. Contudo, mudar nossos paradigmas não é tarefa fácil, pois é preciso converter o olhar auto-referenciado em um conjunto de propostas capazes de integrar as experiências, os sentidos e as sensibilidades do outro em um mesmo plano de análise. 
Sabemos destas dificuldades e tentamos nos desviar delas elegendo bibliografias de ambos os países que fizessem análises históricas com escolhas documentais alargadas e/ou diferenciadas (fontes orais, fontes oficiais, fontes literárias de vários tipos...), que deram ênfase também à análise das narrativas e dos discursos (tanto os preponderantes como os que foram silenciados).

Como complemento buscamos algumas fontes oficiais e dados estatísticos, porém sabemos que os números podem conter erros e falsear dados, por isso precisam ser analisadas frente a outras fontes. Desta forma, objetivamos apresentar uma revisão bibliográfica dos principais aspectos levantados no Brasil e em Portugal sobre a institucionalização das escolas de formação de professores/as e a sua relação com a feminização do magistério primário, tendo o cuidado de tentar compreender os sentidos históricos que foram dados por cada país, em cada momento.

Deste processo, consideramos que um dos primeiros passos para que acontecesse a feminização do magistério e o afastamento dos homens da docência foi a forma como se deu institucionalização das escolas de formação de professores/as. Uma história de luta feminina frente aos discursos discursos favoráveis e negativos à sua entrada nos cursos de formação para o magistério, de crescimento do número de mulheres nos cursos e de saída dos homens do mesmo, de valorização da condição feminina e do status da profissão, de abertura profissional às mulheres, entre outros aspectos.

Como nos aponta Nóvoa (1987: 320) a construção da profissão docente é um processo muito complexo, que não pode ser estudado de forma rígida e simplista, como se as diferentes etapas se sucedessem inexoravelmente à outras. Interessamo-nos pelas grandes fases de construção da profissão docente, mas sabemos que dentro delas há contradições; enfim, os passos que destacamos foram acompanhados de vários discursos (favoráveis e desfavoráveis), ações, avanços e retrocessos, enfim, de uma complexidade de fatores que não nos permite apontar uma causa e um caminho linear para esta feminização. Ao contrário, várias descontinuidades, continuidades e rupturas marcam de forma mais forte este processo. Assim, parafraseando Nóvoa (1992), este não se trata de um texto fechado, mas de idéias abertas, que esperamos que possam ser cada vez mais abertas.

Portanto, neste artigo conferimos, resumidamente, como aconteceu a formação dos docentes, a entrada das mulheres e a feminização nas instituições de formação docente. Primeiro, analisaremos esta questão em Portugal e depois no Brasil, para depois fazer uma correlação entre as duas histórias. Esperamos, assim como Nóvoa (1991), que ao reavivar esta memória possamos contribuir para a produção de novos futuros da profissão docente.

Para Almeida (1998: 75-76) a "feminização do magistério trouxe também a feminização do curso de formação, ou vice-versa, não se podendo afirmar o que começou primeiro". A entrada maciça das mulheres na profissão mudou a escola como instituição, pois logo após terem ocupado o magistério primário, as mulheres conseguiram acesso ao secundário, puderam freqüentar as universidades, e, paulatinamente, foram dirigindo-se para outras profissões.

Desta forma, o magistério primário também representou o ponto de partida das conquistas e das lutas femininas (que progressivamente foram estendidas das classes médias e altas para as classes trabalhadoras, que também passaram a ingressar no magistério). Outros autores, como Werle (2005), também focalizam a formação inicial como um fator de feminização do magistério, como divulgadores de forma de ser "professor/a".

Argumentos parecidos são referidos por autores portugueses. Araújo (2000: 110) defende que, associada à pouca possibilidade de trabalho além da docência, as mulheres se apropriaram do ensino como forma de proporcionarem uma vida mais independente, o que era possibilitado com a entrada nas Escolas Normais ${ }^{1}$. Benavente (1990: 81) também cita a distribuição geográfica das Escola Normais em Portugal que tornava esta formação mais 
acessível às raparigas do que outros cursos médios como uma das razões ${ }^{2}$ para a feminização da profissão docente (que não aconteceu somente em Portugal).

A formação de professores é, como afirma Nóvoa (1992: 18), um "momento-chave da socialização e da configuração profissional", por isso destacamos que a entrada e a feminização do corpo discente (e docente) das Escolas Normais foi um dos maiores potenciadores da feminização do magistério, entendida como o aumento quantitativo das mulheres na docência e da circulação de discursos defensores da entrada (e predomínio) das mulheres no magistério e das qualidades ditas "femininas" para o exercício desta profissão.

\section{Escolas de formação de professores/as em Portugal}

A primeira preocupação com a formação de professores em Portugal (que se estendeu ao Brasil) é introduzida em 1815 com as discussões sobre o método mútuo (ou lancasteriano, baseado em modelo inglês), em 1816 cria-se uma escola normal em Lisboa para a difusão desse método, pela primeira vez os professores foram escolarmente preparados para o desempenho da profissão, mas essa proposta visava a melhoria do exército (só alguns civis, crianças e adultos, tiraram proveito). Em 1824 é criada uma Escola Normal em Lisboa para divulgar este método a professores que já estavam em exercício e os seus discípulos passam a ter preferência nos concursos ${ }^{3}$ (CARVALHO, 1986: 529-547). Nóvoa (1987: 427-30) destaca que de 1816 a 1844 são implementados os primeiros esforços para organizar o ensino normal ${ }^{4}$, difundindo o método mútuo aos professores. Em 1830 são criadas 14 escolas normais para difundir o ensino mútuo, mas seu funcionamento é irregular e contribui muito pouco para a formação de professores ${ }^{5}$.

Araújo (2000: 106) observa que só em 1863 a Escola Normal passa a ser uma instituição exclusiva para formar professores, preenchida por estudantes do sexo masculino de classes médias baixas, onde em algumas escolas os alunos recebiam subsídios (que foram cortados em $1903^{6}$ ). Mas Nóvoa (1987) afirma que a criação da primeira escola normal ${ }^{7}$ não significou um avanço imediato na formação dos professores, pois os esforços na divulgação do ensino normal é baixo, durante o século XIX a admissão ao magistério faz-se por exame público, não exige formação específica.

Nóvoa (1987: 433-444) ressalta o período de 1862 a 1881 como a fase de criação das primeiras escolas normais, que usavam o método português experimental, eram organizadas segundo modelo dos seminários religiosos (deve-se constatar se o aluno tem "vocação" para o ensino e expulsar os incapazes de exercer o magistério, adota-se o regime de internato porque o "sacerdote do ensino" deve habituar-se a regras de disciplina, horários, rezas, higiene e devem praticar a agricultura, pois recebem pouco). Mas o número de formados é pequeno, assim como o número de mulheres na profissão, de acordo com os dados de 1875 apresentados por Nóvoa (1987, pp. 374-409) só 5\% dos professores/as tem o curso normal (50\% tem só entre 3 a 4 anos de estudo); 80,4\% dos professores/as são homens e 19,6\% são mulheres, 1/5 dos professores/as são religiosos e a maioria tem entre 31 e 40 anos $^{8}$.

A primeira Escola Normal feminina é criada em $1866^{9}$, em Lisboa, em um orfanato para raparigas (que funcionava em um edifício de uma escola conventual ${ }^{10}$ ), as alunas eram recrutadas em asilos, adotava-se o regime de internato, com ensino voltado aos trabalhos "femininos" e ao ensino religioso. Forma-se nesta escola 141 professoras até 1881 (NÓVOA, 1987; ARAÚJO, 2000). Apesar de ainda ser um número pequeno, vários fatores vão desencadear o aumento do recurso a uma força de trabalho feminina no magistério, entre 1870 e 1910, o Estado incorpora as mulheres, adota políticas que mudaram o ensino em termos de relações de gênero, como a igualdade salarial e a expansão das Escolas Normais femininas e masculinas em igual número (ARAÚJO, 2000: 109-10).

Entre 1881 a 1901, Nóvoa (1987: 430; 474-475) identifica um período de expansão das escolas normais, pois a Reforma de 1878 cria 4 escolas: 2 em Lisboa e 2 no Porto (uma para 
cada sexo $\left.{ }^{11}\right)$ e 10 escolas normais "mistas"12 de segunda classe, uma em cada capital de distrito (contudo algumas não são criadas $^{13}$ ). Em 1896 as Escolas de Habilitação para o Magistério Primário são criadas, assim, no período entre 1896 a 1901, são abertas 18 Escolas do Magistério Primário, mas as Escolas Normais passam a restringir-se a Lisboa e Porto ${ }^{14}$.

No ensino primário as mulheres eram aceitas, mas o primeiro liceu ${ }^{15}$ feminino só abre em $1906^{16}$. Assim, as mulheres não tinham condições (ou tinham muitas dificuldades) para cursar a Universidade, só continuavam os seus estudos nas Escolas Normais (CARVALHO, 1986: 646; 683). Isso favoreceu que o número de mulheres formadas nas escolas normais ultrapassasse o número de homens no período entre 1883-1892, e continuasse a crescer até 1926, conforme podemos ver na tabela 1 e 2 seguir:

Tabela 1 - Número de Professores/as das Escolas Normais/Magistério Primário de Portugal e de Alunos

\begin{tabular}{|c|c|c|c|c|c|c|}
\hline \multicolumn{7}{|c|}{ Matriculados } \\
\hline Período & $\begin{array}{r}\mathrm{N}{ }^{\circ} \mathrm{de} \\
\text { Professores }\end{array}$ & $\begin{array}{r}\mathrm{N}^{\circ} \mathrm{de} \\
\text { Professoras }\end{array}$ & $\%$ Professoras & N..$^{\circ}$ de Alunos & N. ${ }^{\circ}$ de Alunas & $\%$ Alunas \\
\hline 1918-19 & 145 & 50 & 25,6 & 761 & 2801 & 78,6 \\
\hline $1920-21$ & 64 & 8 & 11,1 & 113 & 449 & 79,8 \\
\hline $1922-23$ & 77 & 12 & 13,4 & 94 & 543 & 85,2 \\
\hline $1925-26$ & 76 & 13 & 14,6 & 90 & 724 & 88,9 \\
\hline $1926-27$ & 73 & 12 & 14,1 & 99 & 694 & 87,5 \\
\hline $1928-29$ & 62 & 12 & 16,2 & 123 & 579 & 82,4 \\
\hline $1930-31$ & 61 & 21 & 25,6 & 418 & 825 & 66,3 \\
\hline $1932-33$ & 19 & 3 & 13,6 & 243 & 282 & 53,7 \\
\hline $1977-78$ & - & - & - & 1.669 & 4.826 & 74,3 \\
\hline $1978-79$ & - & - & - & 1.025 & 2.860 & 73,6 \\
\hline $1979-80$ & - & - & - & 491 & 1.686 & 77,4 \\
\hline $1980-81$ & - & - & - & 330 & 1.516 & 82,1 \\
\hline $1981-82$ & - & - & - & 342 & 1.847 & 84,4 \\
\hline $1982-83$ & - & - & - & 393 & 2.168 & 84,7 \\
\hline $1983-84$ & - & - & - & 520 & 2.966 & 85,0 \\
\hline $1984-85$ & - & - & - & 562 & 3.638 & 86,6 \\
\hline $1985-86$ & - & - & - & 615 & 3.942 & 86,5 \\
\hline $1986-87$ & - & - & - & 468 & 2.951 & 86,3 \\
\hline
\end{tabular}

Fonte: Araújo (2000: 190, 191, 208, 209): De 1918 a 1933. GIASE (2006b): De 1977 a 1988.

Tabela 2 - Número de Formados/as nas Escolas Normais de Portugal

\begin{tabular}{|l|r|r|r|}
\hline Período & N. ${ }^{\circ}$ de Formados & N. ${ }^{\circ}$ Formadas & \% de Formadas \\
\hline De 1862 a 1871 & 91 & 44 & 32,5 \\
\hline De 1872 a 1881 & 103 & 97 & 48,5 \\
\hline De 1883 a 1892 & 190 & 307 & 61,7 \\
\hline De 1893 a 1902 & 338 & 760 & 69,2 \\
\hline De 1920 a 1921 & 113 & 449 & 79,8 \\
\hline De 1922 a 1923 & 94 & 543 & 85,2 \\
\hline De 1925 a 1926 & 90 & 724 & 88,9 \\
\hline De 1926 a 1927 & 99 & 694 & 87,5 \\
\hline De 1928 a 1929 & 123 & 579 & 82,4 \\
\hline De 1930 a 1931 & 418 & 825 & 66,3 \\
\hline De 1932 a 1933 & 243 & 282 & 53,7 \\
\hline
\end{tabular}

Fonte: Período de 1862 a 1902: Baseado nos dados referidos por Nóvoa (1987: 475), de 1862 a 1902, não inclui as Escolas de Habilitação para o Magistério Primário porque não existia o número de formados separado por sexo. Período de 1920 a 1933: Araújo (2000: 190; 208). 
No início do século XX, as Escolas Normais conquistaram em lugar sólido no sistema de ensino do Estado ${ }^{17}$ : em 1901 publica-se a Reforma do Ensino que obrigava a ter o diploma do curso normal para se candidatar ao exercício do magistério primário. Assim, de acordo com Nóvoa (1988), os anos de 1901 a 1933 constituem a idade de ouro dos professores/as da instrução primária ${ }^{18}$, pois os docentes serão capazes de fazer um resgate crítico e refletivo de sua própria história profissional, constituem associações profissionais e conquistam direitos (como aumento de remuneração, alongamento da duração da formação, a melhora do nível acadêmico do curso normal ${ }^{19}$, a elaboração de teorias científicas, entre outras). A primeira República é considerada um dos tempos quentes da história portuguesa dentro do processo de construção da profissão docente ${ }^{20}$ (o outro seria a época pombalina) ${ }^{21}$ (NÓVOA, 1987: 475; 517-518; 691). Este período representou um tempo de muitas certezas e uma crença quase ilimitada nas potencialidades da escola, onde o professorado constrói o seu estatuto sendo apóstolos e porta-vozes desta visão idílica (e ingênua) da instituição escolar e da sociedade (NÓVOA, 1988: 6).

Todavia, dentro desse período também há retrocessos: a Reforma de 1911 reduz o número de escolas normais para três - em Lisboa, Porto e Coimbra (em regime de coeducação), as outras poderiam ser criadas se as autoridades regionais assumissem os custos da instalação. Os inscritos no $1 .^{\circ}$ ano de funcionamento (em 1918) foram de 15,4\% homens e 84,6 mulheres. Mas de 1930 a $193642 \%$ dos inscritos nos cursos são do sexo masculino e estes são 35\% dos formados de 1930 a 1938, o que pode ser causado pela repercussão da elevação do salário (NÓVOA, 1987: 673; 690).

Para Nóvoa a formação dos professores/as é mais do que um lugar de aquisição de técnicas e de conhecimentos, é o momento-chave da socialização e da configuração profissional. A percepção deste fato levou o Estado Novo a tomar medidas radicais nesta área $^{22}$ : primeiro tenta várias vezes reformar as escolas normais republicanas, depois, encontrando resistência, decide fechar as escolas em 1936. Ao mesmo tempo em que desvaloriza o estatuto da profissão docente e exerce um controle autoritário dos professores/as, o Estado Novo dignifica a sua imagem social, dando-lhe um aspecto missionário para salvaguardar a imagem e o prestígio dos professores/as junto das populações (1991: 109; , 1992: 18).

Dentre as medidas radicais, destaca-se: em Junho de 1926 a extinção das Escolas Normais Superiores $^{23}$. Em Abril de 1928 as Escolas Normais Primárias são fechadas, sendo reabertas em Agosto $^{24}$, com uma diminuição das habilitações para o ingresso ${ }^{25}$. Em Julho de 1930 as Escolas Normais são substituídas por Escolas do Magistério Primário destinadas a formar professores/as primários elementar e do ensino infantil ${ }^{26}$, reduz-se de novo a escolaridade de ingresso (sendo necessário só o ensino primário elementar) e exigia-se exame para o exercício do magistério ${ }^{27}$. Por fim, em Novembro de 1936 encerra-se as Escolas do Magistério Primário (CARVALHO, 1986: 732). Para Nóvoa, o fechamento das escolas de magistério primário no ano de 1936 marca a decadência do Ensino Normal em Portugal (NÓVOA, 1987: 690).

Em Novembro de 1930 são criados os "postos de ensino"28 onde os "regentes escolares" ensinariam $^{29}$, precisando comprovar apenas idoneidade moral e intelectual ${ }^{30}$ (em 1935 passa-se a exigir exame de aptidão para os regentes, havia regentes que não sabiam escrever), considerava-se que era necessário pagar uma pequena remuneração em prol da diminuição do numero dos iletrados e que para transmitir tão limitados conhecimentos não se precisava de preparação específica (CARVALHO, 1986). Mónica (1978: 205) considera a nomeação dos regentes escolares uma ajuda à degradação do status do professor e da qualidade do ensino. Nóvoa (1991: 112) também compreende esta ação como um dos aspectos de uma estratégia que conduz a uma desvalorização do professorado, tanto ao nível econômico como profissional e científico. 
Contudo, Guinote (2006) demarca que essa é uma leitura parcial da questão ${ }^{31}$, que reduz a importância de milhares de profissionais - o(a)s regentes escolares - que, com baixa qualificação e remuneração, exerceram o ensino das primeiras letras em meios onde ele não teria existido de outra forma e contribuiram para o alargamento do ensino e a diminuição do analfabetismo $^{32}$. Essa profissão possibilitou uma maior penetração da mulher no mercado de trabalho: em 1940/41 eram 83,6\% de mulheres, 95,6\% em 1950/51 e chega a praticamente $100 \%$ na década de $60^{33}$. No início dos anos 50, a proporção de regentes frente aos professores/as era perto dos 30\% e em 1955/56 sobe para cerca de 45\%, mas começa a decrescer na década de 60 para menos de $20 \%{ }^{34}$. Mesmo podendo alegar-se que a "qualidade" foi sacrificada, esta política foi utilizada, muitas vezes a contra-gosto, para combinar o controle ideológico da escola, a expansão da alfabetização e a contenção orçamental.

Quanto à formação de professor, esta ficou por um bom tempo deixada de lado, pois as Escolas do Magistério Primário são reabertas em 1943 (com um curso reduzido de 3 para 2 anos, ministrado em 4 escolas - Lisboa, Porto, Coimbra e Braga) motivada pela falta de professores/as primários ${ }^{35}$, que foi agravada ainda mais com a construção de escolas previstas no "Plano dos Centenários" em $1940^{36}$ (CARVALHO, 1986: 732). Mas a reabertura é marcada pela modificação completa: apaga-se a memória do ensino normal, introduz-se uma visão minimalista da formação e das suas bases científicas, ou seja, meramente tecnicista e didática, enfatizando a "moral" e o domínio de certos métodos de ensino. O Estado Novo considerava que um elevado nível acadêmico não era necessário, assim, o estatuto sócio-econômico cai e a visão missionária/religiosa da atividade docente é recuperada (NÓVOA, 1991: 109).

Serra (2004: 34-35) identifica no discurso de muitos diretores das Escolas do Magistério Primário (que assumiram estes postos após o período ditatorial) o repúdio a tais orientações imprimidas durante o Estado Novo no domínio da formação de professores do ensino primário, estas escolas eram criticadas por ser o setor de ensino mais abandonado e retrógrado do sistema escolar português e que mais não eram do que um instrumento decisivo e essencial de reprodução da ideologia do Estado e de manutenção dos privilégios da minoria exploradora, isso produzir como efeito o desprezo à formação do professor.

Nóvoa (1991: 117) sustenta que os anos trinta desencadearam uma política sistemática de degradação do estatuto dos professores, que nos retirou até a "memória" da profissão docente; desta forma (ao contrário do que pode parecer), não há um hiato na história do país e dos professores durante o período ditatorial, ao contrário, existe um recuo da profissionalização da atividade docente, que pode verificar-se: na tendência de acumular funções; na desvalorização da permissão para ensinar; na diminuição do nível da formação docente; na interdição das associações profissionais docentes; na falta de um saber próprio a atividade docente; na imposição de uma ética e um comportamento deontológico aos docentes. Isso não conduz a uma nova identidade profissional, mas à degradação do status sócioeconômico dos docentes (NÓVOA, 1987: 766-772). Em 1960, as consequiências mostram-se claramente: Portugal aparece em último lugar nas estatísticas européias (NÓVOA, 1992: 1920).

Para mudar esta situação, são exigidas mudanças na política educativa. Assim, a década de 1970 é marcada pela formação inicial de professores/as ${ }^{37}$, o Ensino Normal Primário ganha novo impulso depois do 25 de Abril de $1974^{38}$, o apoio do Banco Mundial (principalmente na criação das Universidades Novas) torna-se decisivo para lançar uma rede de Escolas Superiores de Educação nas Universidades, o que contribui para o desenvolvimento das Ciências da Educação (NÓVOA, 1992: 20) 39 .

Após 1974 as Escolas do Magistério Primário passam por várias reestruturações curriculares $^{40}$ propondo-se aumento de estatuto (para ensino médio superior), maior escolaridade para aceder ao curso ( $7 .^{\circ}$ ano do liceu), interdisciplinaridade, além disso, estas escolas passam em 1974 por um regime de "experiência pedagógica"41 (ALMEIDA, 1981; 
BENAVENTE, 1990; SERRA, 2004). No fim da década de 70 Serra (2004: 226-7) indica que a formação de professores tinha dois eixos: os professores primários e educadores de infância nas do magistério primário e normais (instituições de "ensino médio") e dos professores para ensino preparatório e secundário nas universidades. Mas com a criação do ensino superior de curta duração e das Escolas Superiores de Educação - ESE's (institucionalizados pelo decretolei . $^{\circ} 427-\mathrm{B} / 77$, ratificado e emendado pela lei . $^{\circ} 61 / 78^{42}$ ) surgem instituições de formação de professores que resultariam assim de reconversão das escolas normais de educadoras de infância e das escolas do magistério primário ${ }^{43}$.

Porém, contrariando algumas expectativas mais otimistas, o processo de reconversão institucional das escolas de magistério para ensino superior apenas viria a ocorrer de modo conseqüente a partir da década de oitenta. Apenas em Maio de 1986 é publicado um diploma que estabelecerá um adequado esquema programático de extinção das escolas do magistério primário e do magistério infantil ${ }^{44}$, face à progressiva entrada em funcionamento das ESE's e CIFOP's, como isso teria um custo alto foi dividido em duas fases: as matrículas nas escolas do magistério seriam suspensas à medida que fosse possível abrir as matrículas nas ESE's e CIFOP's (SERRA, 2004: 230-232) ${ }^{45}$.

Em 1986 é publicada a Lei de Bases do Sistema Educativo (Lei n. ${ }^{\circ}$ 46/86, de 14/10) que institui a formação inicial de nível superior e uma formação contínua aos docentes. No entanto, a formação inicial dos educadores de infância, dos professores/as de $1 .^{\circ}$ e $2 .^{\circ} \mathrm{CEB}$ realiza-se em escolas superiores de educação (ou em universidades, com diplomas de bacharéis equiparados aos das ESE's), já dos professores/as do $3 .^{\circ} \mathrm{CEB}$ e de professores/as do ensino secundário realiza-se só em universidades (o que torna ainda nítida uma clivagem na formação). Em 1997 esta lei é alterada (pela Lei n. ${ }^{\circ} 115$ ) e os professores/as até o $3 .^{\circ} \mathrm{CEB}$ passam a formar-se em grau de licenciatura tanto em escolas superiores de educação como em estabelecimentos de ensino universitário (mas os professores de ensino secundário só formamse em universidades). Em 2005 a lei é novamente alterada (pela Lei n. ${ }^{\circ}$ 49) e define a formação de todos os professores/as em linhas gerais "através de cursos superiores organizados de acordo com as necessidades do desempenho profissional no respectivo nível de educação e ensino".

Enfim, o século XX é descrito por Nóvoa (1989: 449) como uma longa sucessão de fracassos das "grandes Reformas do ensino" e, como provocação, afirma que o único regime político que não tentou fazer uma reforma do ensino com $\mathrm{R}$ grande foi o Estado Novo "ele terá sido, porventura, o único regime que teve êxito na sua estratégia, conseguindo ajustar o sistema educativo à medida das suas necessidades". Mesmo assim considera que o Estado Novo representou um "duro golpe" que deixou "cicatrizes" que podem ser traduzidas em dois eixos na formação docente até a década de 1960: redução ${ }^{46}$ e controle (NÓVOA, 1991: 109).

Nóvoa (1992: 21-23) assinala como marca da década de 1980 a profissionalização em serviço (motivada pela explosão escolar que trouxe indivíduos sem habilitação acadêmica e pedagógica para a docência), junto com a acentuação progressiva dos fatores de mal estar profissional. Este fato tem, ao mesmo tempo, uma importância quantitativa e estratégica, mas também aguça uma visão degradada/desqualificada dos professores/as e o papel do Estado no controle da profissão docente ${ }^{47}$, pondo em causa a autonomia relativa conquistada pelas instituições de formação docente. Já a década de 1990 é marcada pela formação contínua, com a formação inicial em vias de resolução vira-se para a formação contínua para assegurar o sucesso das reformas educativas e assegurar a concretização do estatuto da carreira docente ${ }^{48}$.

Conforme Benavente (1990: 41-42) aponta, não é fácil descrever consensualmente sobre o que mudou ou não na educação portuguesa após o 25 de Abril. Alguns assuntos destacados são a dignificação do estatuto docente, as mudanças curriculares e a tentativa de democratização, mas "a distância entre o ideal e o real é um dos pontos que reúne a unanimidade junto dos que se interessam pela educação". Essa distância pode ter algumas 
razões demarcadas como: a burocracia da máquina administrativa (que apela para a normalização); a falta de recursos materiais e humanos (alguns destacam o corpo docente como conservador, o que seria de difícil resolução imediata); a ausência de um projeto global e coerente e a centralização das decisões. Contudo, a autora não acusa o Estado após 1974, mas demarca que é preciso ter em conta as exigências e lógicas institucionais, grupais e individuais para mudar democraticamente a instituição e as suas práticas (1990: 263).

Desta forma, notamos que a feminização da docência primária continua até hoje em Portugal $^{49}$ (ver tabela 3), trazendo discursos do passado que, atualmente, apropriados e modificados, continuam trazendo consequiências nas escolhas, representações e atuações destes profissionais. Assim, concordando com Benavente, sabemos que somente com o conhecimento e reflexão sobre estes referenciais a mudança pode ser possível.

Tabela 3 - Número de Professores/as Primários em Portugal

\begin{tabular}{|c|c|c|c|}
\hline Período & N. ${ }^{\circ}$ de Professores & N. ${ }^{\circ}$ de Professoras & $\%$ de Professoras \\
\hline 1771 & 440 & - & - \\
\hline 1800 & - & 0 & - \\
\hline 1814 & - & 21 & - \\
\hline 1829 & - & 28 & - \\
\hline 1844 & - & 41 & - \\
\hline $1854-55$ & 1.146 & 53 & 4,5 \\
\hline 1862 & - & 153 & - \\
\hline $1868-69$ & - & 362 & - \\
\hline 1875 & - & 594 & 19,6 \\
\hline 1881 & - & 848 & - \\
\hline $1881-82$ & 2.364 & 914 & 27,8 \\
\hline 1889 & - & 1.338 & - \\
\hline $1899-00$ & 2.825 & 1.670 & 37,2 \\
\hline 1900 & - & 1.670 & - \\
\hline $1909-10$ & - & - & 52,2 \\
\hline $1910-11$ & 2.777 & 3.031 & 52,2 \\
\hline $1915-16$ & 3.033 & 4.594 & 60,2 \\
\hline $1916-17$ & - & - & 69,9 \\
\hline $1918-19$ & 3.038 & 4.902 & 61,7 \\
\hline $1925-26$ & 2.865 & 5.619 & 66,2 \\
\hline $1926-27$ & 2.778 & 5.619 & 66,8 \\
\hline $1928-29$ & 2.691 & 6.357 & 70,2 \\
\hline 1929-30 & - & - & 71,6 \\
\hline $1930-31$ & 3.030 & 6.310 & 67,5 \\
\hline $1932-33$ & 2.906 & 6.791 & 70,0 \\
\hline $1940-41$ & - & - & 75,6 \\
\hline 1948 & - & - & 80,5 \\
\hline 1955 & - & - & 85,6 \\
\hline 1963 & - & - & 96,5 \\
\hline 1971 & - & - & 88,9 \\
\hline 1977 & - & - & 91,9 \\
\hline 1983 & - & - & 91,8 \\
\hline $1994 / 95$ & 2.393 & 28.882 & 92,3 \\
\hline $1995 / 96$ & 2.328 & 28.830 & 92,5 \\
\hline $1996 / 97$ & 2.441 & 30.470 & 92,6 \\
\hline
\end{tabular}




\begin{tabular}{|l|l|l|r|}
\hline $1997 / 98$ & 2.322 & 29.564 & 92,7 \\
\hline $1998 / 99$ & 2.819 & 29.868 & 91,4 \\
\hline $1999 / 00$ & 2.930 & 31.073 & 91,4 \\
\hline $2000 / 01$ & 2.932 & 31.063 & 91,4 \\
\hline $2001 / 02$ & 2.979 & 32.207 & 91,5 \\
\hline $2002 / 03$ & 2.784 & 31.732 & 91,9 \\
\hline $2003 / 04$ & 3.043 & 31.561 & 91,2 \\
\hline $2004 / 05$ & 3.101 & 34.113 & 91,7 \\
\hline
\end{tabular}

Fonte: Carvalho (1986): ano de 1771.

Araújo (2000: 77; 94; 211): anos de 1854-55, 1868-69, 1881-82, 1899-00, 1910-11, 1915-16, 1918-19, 1925-26, 1926-27, 1928-29, 1930-31, 1932-33.

Nóvoa (1987: 734; 594; 788): anos de 1800, 1814, 1829, 1844, 1854, 1862, 1869, 1875, 1881, 1900, 1899-1900, 1909-1910, 1916-1917, 1925-1926, 1929-1930, 1940-1941, 1948, 1955, 1963, 1971, 1977, 1983.

GIASE (2006c: 28; 114) anos de 1994/95 a 2003/04 (dados sobre professores do ensino público). Cabe observar que no ensino privado as mulheres eram 95,7\% em 1994/95, mas decresceu para 88,2\% em 2003/04, o que mostra que talvez exista uma vantagem no acesso dos homens no ensino particular).

GIASE (2006a: 37) dados de 2004/05.

\section{Escolas de formação de professores/as no Brasil}

A formação de professores em escolas liga-se à institucionalização da instrução pública e os movimentos da Reforma e Contra-Reforma, assim, somente no século XIX com a Revolução Francesa a idéia de uma escola normal a cargo do Estado encontra condições favoráveis (MARTINS, 1996; TANURI, 2000). Antes disso somente existiram preocupações no sentido de selecionar os professores ${ }^{50}$, em $1827^{51}$, por exemplo, são criadas escolas em todas as cidades, vilas e lugares mais populosos do Brasil/Império, como consequiência seleciona-se mestres e mestras (embora as mulheres fossem dispensadas destes exames e, por isso, recebiam menos). O primórdio da preparação de professores no Brasil foram as escolas de ensino mútuo ${ }^{52}$ : em 1823 cria-se uma escola de primeiras letras pelo método de ensino mútuo para instrução das corporações militares, mas só em 1827 a instituição do ensino mútuo no Brasil é consagrada na lei (TANURI, 2000: 62-63).

Tanuri (2000: 64-65) descreve que as primeiras escolas normais brasileiras só são estabelecidas logo após a descentralização de 1834 que deixava a sua criação a cargo das Províncias $^{53}$ : a primeira escola normal brasileira masculina ${ }^{54}$ foi criada em 1835 em Niterói na Província do Rio de Janeiro, usava o método mútuo (lancasteriano), mas teve duração efêmera, sendo suprimida em $1849^{55}$. Nos anos que se seguiram à criação da primeira escola normal, a experiência se repetiu em outras províncias, porém a formação de professores não era compreendida como necessária, havia falta de interesse da população pela profissão docente (a julgar pelos depoimentos da época) acarretada pelo pouco apreço e pelos baixos atrativos financeiros que o magistério primário oferecia ${ }^{56}$. Além disso, a formação não era exigência para a docência: algumas províncias recrutavam os professores a partir de exames ou concursos (onde bastava saber ler, escrever, as quatro operações e orações), outras (como o Rio de Janeiro de 1849 a 1854) adotavam o sistema de "professores adjuntos"57.

De acordo com Villela (2000), estas escolas nasceram buscando uma uniformidade por meio da instrução, elas eram os locais "autorizados" para a difusão de um tipo de conhecimento normatizado que deveria caracterizar o "novo" professor primário, enfim, formariam aqueles homens a quem caberia, por missão, elevar o nível intelectual e moral da população, unificando padrões culturais e de convivência social. No entanto, Tanuri (2000: 6465) afirma que nos primeiros 50 anos do Império, as poucas escolas normais do Brasil não foram além de ensaios rudimentares e mal sucedidos, e tiveram algumas características comuns: foram destinadas exclusivamente aos elementos do sexo masculino (as mulheres 
eram excluídas ou previa-se a futura criação de escolas normais femininas); tinham somente 1 professor (ou dois); um curso de dois anos; seu currículo não ultrapassava o conteúdo dos estudos primários (acrescido de rudimentar formação pedagógica); tiveram pouquíssimos alunos; foram freqüentemente fechadas e reabertas (por falta de alunos ou por descontinuidade administrativa) (Tanuri, 2000, pp. 64-65). Além disso, Kulesza (1998: 65-66) indica que muitas províncias criaram um curso Normal anexo ao Liceu ${ }^{58}$, antes de fundarem uma Escola Normal $^{59}$.

Algumas Escolas Normais Femininas foram abertas, mas de início também não tiveram grandes repercussões. Em 1847 foi criada uma Escola Normal Feminina no Seminário Glória (SP) que, inicialmente, destinava-se às órfãs sem dote ${ }^{60}$ e às jovens de poucos recursos que precisavam trabalhar para sobreviver ${ }^{61}$. Em 1856 esta escola passa a ter seção feminina e masculina, mas fecha em 1878 por falta de verbas, reabrindo em 1880 . De 1880 a 1883 teve maioria feminina nas matrículas, mas de 1881 a 1893 formou 269 rapazes e 238 moças, o que mostra que elas procuravam o curso em maior número, porém nem todas se formavam. $\mathrm{Na}$ proclamação da República (em 1888) as mulheres já eram maioria nos cursos normais de São Paulo $^{62}$ (Almeida, 1998, pp. 58-61). No Rio de Janeiro, a Escola Normal de Niterói é reaberta em 1862 e começa a funcionar também com a presença feminina (estudando com currículo diferente e em dias alternados dos meninos) (Bruschini \& Amado, 1988, p. 5), a Escola Normal da Corte (Rio de Janeiro) começa a funcionar em 1877 com 88 meninas e 87 rapazes inscritos (SANTOS, 2004).

Kulesza (1998: 66-68) descreve que, no início, as escolas normais em regime de coeducação (que aceitavam mulheres), eram na prática masculinas, porque a co-educação era difícil de concretizar, não se queria que as mulheres estudassem com os homens. Algumas estratégias foram usadas para que não se temesse/impedisse que as mulheres estudassem junto dos homens nas escolas normais, como, por exemplo, a construção de uma parede no meio da sala para que homens e mulheres não se comunicassem (Pernambuco em 1880) e a transformação destas escolas em exclusivamente femininas (o que aconteceu em várias escolas normais desde o século XIX até meados do século XX). Contudo, em alguns lugares do Brasil não foi assim, Werle (2005) diz que no Rio Grande do Sul a feminização das matrículas na Escola Normal ocorreu desde o início, apesar da indicação de que esta escola seria somente masculina, atendendo às órfãs internas do colégio que ficava ao lado desta.

É no contexto de um ideário de popularização do ensino a partir de $1868 / 70$, que as escolas normais passam a ser reclamadas com maior constância e coroadas de algum êxito ${ }^{63}$. Em 1867 havia 4 estabelecimentos no país, em 1883 registrava-se 22 (quase todas as províncias empenharam-se em criá-las e ocorre um enriquecimento de seu currículo ${ }^{64}$ ). Assim, nos anos finais da monarquia/Império, as escolas normais foram sendo abertas às mulheres, 0 que imprimiu fortes possibilidades de acesso a instrução pública e favoreceu a abertura de um espaço profissional às mulheres ${ }^{65}$; exclusivamente femininas ou em regime de co-educação, a frequiência feminina começa a predominar, junto com a defesa da idéia de que a educação da criança deveria ser-lhe atribuída, como ampliação do seu papel de mãe (BRUSCHINI e AMADO, 1988: 5; ALMEIDA, 1998: 65; TANURI, 2000: 66; VILLELA, 2000).

De acordo com Almeida, na primeira metade do século XX, o magistério primário no Brasil sofreu um processo de feminização tanto na freqüência das Escolas Normais ${ }^{66}$ pelas moças como pela ocupação do magistério pelas mulheres ${ }^{67}$ (o que, em parte, pode ser explicado pelo crescimento da escolaridade obrigatória feminina a partir de $1827^{68}$ ) (Almeida, 1998, p. 65). Mas, algumas vezes, a freqüência das Escolas Normais não aconteceu antes da ocupação do magistério pelas mulheres, Schaffrath (2000: 13), por exemplo, indica que o Governo provincial de Santa Catarina precisou admitir professoras em seus quadros para regerem as poucas escolas femininas que foram criadas. Conseqüentemente, em 1892 quando é criada a Escola Normal, 63\% das matrículas foram femininas e até 1907 esta escola havia 
formado 49 alunas e 6 alunos (21 exerceram o magistério público estadual $)^{69}$. Muitas alunas já lecionavam e foram obrigadas pelo Governo a cursar a Escola Normal, outras se tornavam professoras em escolas particulares ou atendiam a domicílio os filhos das ricas famílias, sobre outras não há noticia de atuação docente, o que pode indicar que o diploma de normalista tenha servido apenas como uma espécie de dote cultural para moças, filhas das elites ou pequena burguesia, que desejavam uma cultura enciclopédica, para ornamentar seus dotes para o casamento.

No final do Império, a maioria das províncias não tinha mais do que uma escola normal pública (quando muito duas: uma para cada sexo), geralmente com 3 anos de estudos, que não alcançavam ainda o nível do curso secundário (sendo inferiores no conteúdo e na duração dos estudos). Cabe à República ${ }^{70}$ a tarefa de desenvolver as Escolas Normais e implantá-la como instituição responsável pela qualificação do magistério primário ${ }^{71}$, mas este desenvolvimento é marcado por grandes discrepâncias entre os estados, pois a descentralização continuava. Assim, o desenvolvimento quantitativo e qualitativo da Escola Normal fica sob a liderança dos Estados mais progressistas $^{72}$ (TANURI, 2000: 67-70), junto com a feminização das matrículas nestas escolas e no magistério público (ver tabela 4). De acordo com Villela (2000: 119), em cinco décadas a profissão docente (quase exclusivamente masculina, tornar-se-ia mormente feminina, assim, a formação profissional permitida pelas escolas normais teria papel importante na luta das mulheres pelo acesso a um trabalho digno e remunerado.

Tabela 4 - Número de Professores/as das Escolas Normais, Alunos/as Matriculados/as e Formados/as nas Escolas Normais do Brasil

\begin{tabular}{|c|c|c|c|c|c|c|c|c|c|}
\hline Período & $\begin{array}{r}\mathrm{N}^{\circ} \\
\text { Professo } \\
\text { res }\end{array}$ & $\begin{array}{r}\mathrm{N}^{\circ} \\
\text { Professo } \\
\text { ras }\end{array}$ & $\begin{array}{r}\% \text { de } \\
\text { Professo } \\
\text { ras }\end{array}$ & $\begin{array}{r}\text { Matricul } \\
\text { ados }\end{array}$ & $\begin{array}{r}\text { Matricul } \\
\text { adas }\end{array}$ & $\begin{array}{r}\% \text { de } \\
\text { Matricul } \\
\text { adas }\end{array}$ & $\begin{array}{r}\text { N. }{ }^{\circ} \text { de } \\
\text { Formado } \\
\mathrm{s}\end{array}$ & $\begin{array}{r}\text { N. }{ }^{\circ} \text { de } \\
\text { Formada } \\
\mathrm{S}\end{array}$ & $\begin{array}{r}\% \text { de } \\
\text { Formada }\end{array}$ \\
\hline 1907 & 289 & 221 & 43,3 & 786 & 4.234 & 84,3 & 114 & 540 & 82,7 \\
\hline 1908 & 323 & 245 & 43,1 & 777 & 4.945 & 86,4 & 107 & 720 & 87,1 \\
\hline 1909 & 341 & 263 & 43,5 & 910 & 5.339 & 85,4 & 104 & 865 & 89,3 \\
\hline 1910 & 253 & 249 & 49,6 & 943 & 5.906 & 86,2 & 128 & 977 & 88,4 \\
\hline 1911 & 427 & 293 & 40,7 & 1.128 & 7.042 & 86,2 & 127 & 899 & 87,6 \\
\hline 1912 & 531 & 284 & 34,9 & 1.245 & 8.004 & 86,5 & 155 & 1.072 & 87,4 \\
\hline
\end{tabular}

Fonte: Anuário estatístico do Brazil (BRASIL, 1927): em 1907 eram 44 escolas normais no país sendo 25 mistas e 19 femininas, não existiam escolas masculinas, eram 25 escolas estaduais, 3 municipais e 16 particulares. Em 1908 eram 47 escolas normais no país sendo 27 mistas e 20 femininas, 26 escolas estaduais, 3 municipais e 18 particulares. Em 1909 eram 47 escolas normais no país sendo 26 mistas e 21 femininas, 27 escolas estaduais, 2 municipais e 18 particulares. Em 1910 eram 46 escolas normais no país sendo 22 mistas e 24 femininas, 25 escolas estaduais, 2 municipais e 19 particulares. Em 1911 eram 54 escolas normais no país sendo 29 mistas e 25 femininas, 25 escolas estaduais, 2 municipais e 19 particulares. Em 1912 eram 58 escolas normais no país sendo 29 mistas e 29 femininas, 30 escolas estaduais, 2 municipais e 26 particulares. Parece que as escolas femininas são a maioria das particulares (e a maioria destas encontrava-se em MG).

Vianna (2001/2002: 3) afirma que em grandes cidades como São Paulo e Rio de Janeiro a presença feminina no magistério público primário ganhou destaque; no estado de Minas Gerais elas representam 50\% do corpo docente já no final do século XIX. No estado de São Paulo a presença quotidiana de mulheres não normalistas no magistério primário paulista é registrada no decorrer de todo o século XIX, antes da abertura das escolas normais femininas. No final da década de 20 e início dos anos 30, a maioria das professoras primárias 
já era essencialmente feminina (em 1920 eram 72,5\%), assim "desde o século XIX, pouco a pouco os homens vão abandonando as salas de aula nos cursos primários, e as escolas normais vão formando mais e mais mulheres". Característica que contínua no século XX (inclusive com a ampliação da presença feminina em outros níveis, modalidades de ensino e em outras áreas), estimulada por transformações econômicas, demográficas, sociais, culturais e políticas.

A partir da primeira Guerra mundial há um nacionalismo que se evidencia num entusiasmo pela educação (divulga-se o escolanovismo, a preocupação com estudos, métodos e técnicas de ensino). O ensino normal é dividido na década de 1920 em parte propedêutica e profissional $^{73}$ (no total teria 5 anos), criando-se uma diferenciação de $\operatorname{cursos}^{74}$ que acabaria por consagrar a dualidade de escolas de formação na maior parte dos estados brasileiros, mas que possibilitou a sua maior expansão e consolidação como responsáveis pela preparação do pessoal docente para o ensino primário (TANURI, 2000). Martins (1996) também destaca que até o século XIX qualquer um podia ser professor, na década de 1920 a 1930 há um incentivo à formação do educador e à busca por profissionais bem preparados intelectualmente (assim como por novos espaços escolares), exaltava-se a nobre missão docente e queria-se romper com a imagem que existia que a Escola Normal era um colégio para moças, bom e menos dispendioso que estabelecimentos particulares.

$\mathrm{Na}$ década de 1930 institui-se que o ingresso Escola Normal (que tinha 2 anos de formação profissional e que deveria ter escolas anexas - Primária e Jardim-da-Infância) faz-se após curso secundário ${ }^{75}$, mas o término do curso na Escola Normal só permitia o acesso a alguns cursos superiores, articulação que somente ocorria com alguns cursos das Faculdades de Filosofia, sendo presumível que do ponto de vista do legislador haveria um caminho 'natural' oferecido ao professor primário: do ensino das crianças ao ensino dos adolescentes (TANURI, 2000).

Com a introdução do Estado Novo (em 1937) a educação passa a ser um dos instrumentos do Estado a serviço da Nação para divulgar valores morais. Uma forte onda de civismo impregnava o quotidiano da escola normal (o que é demonstrado inclusive nos periódicos que passam a exaltar Getúlio Vargas, cria-se novos hinos, cultua-se a pátria), mas a nobre tarefa da educação continua a ser elevada. Além disso, há a glorificação das qualidades femininas para a docência presente nos discursos e nas ações ${ }^{76}$ (MARTINS, 1996). Mas ainda não existia escola para atender a todas as jovens ${ }^{77}$.

Em 1945 acaba o Estado Novo e a educação democrática elege o despertar da liberdade: precisava-se de uma formação docente crítica, técnica, cultural, humanitária. Tentava-se apagar as seqüelas do Estado Novo nas práticas educativas (MARTINS, 1996). Assim, em 1946 a Lei Orgânica do Ensino Normal surge como a primeira tentativa de centralização federal do ensino normal ${ }^{78}$, que acaba por consagrar um padrão dualista de ensino normal que já vinha sendo adotado em vários estados ${ }^{79}$ : o $1^{\text {o }}$ ciclo de 4 anos, em Escolas Normais Regionais que forneciam o curso de formação de "regentes" do ensino primário; o 2. ${ }^{\circ}$ ciclo, em dois anos, que formaria o professor primário e era ministrado nas Escolas Normais e nos Institutos de Educação (que também ministravam os cursos de especialização de professores/as, inclusive os cursos de administradores escolares ${ }^{80}$ ou especialistas) (TANURI, 2000).

Esta lei acaba servindo de modelo para a reorganização das escolas normais da grande maioria dos estados, o que contribuiu para que se consolidasse em todo o país um padrão semelhante de formação (em dois níveis de escolas) ${ }^{81}$ e para um crescimento desigualmente distribuído pelo país ${ }^{82}$. Critica-se, porém, a pouca exigência do regime didático, a falta de articulação entre as "cadeiras", o controle ineficiente da rede privada, os cursos normais noturnos, o desvirtuamento das finalidades profissionais das escolas normais, ao lado do reconhecimento das funções "paradomésticas" (TANURI, 2000: 76-78). Ao lado dessas 
críticas, encontramos o argumento de Martins (1996: 199-200) de que esta foi a fase de ouro na formação docente no Rio de Janeiro:

A partir do final da década de 40 e, ao longo da década de 50, vai se construindo, no Instituto de Educação do Rio de Janeiro, a imagem do professor dos "anos dourados". Nesse período, não era permitido o ingresso de rapazes no Instituto de Educação do Rio de Janeiro, consolidando-se, então, a vinculação ensino primário/ tarefa feminina. A existência na formação da professora primária do Instituto estava numa rica ambiência extra-curricular, com uma significativa produção de revistas, que davam voz às alunas e num currículo que primava pela erudição e pelo academicismo. [...] Era bom ser aluna do Instituto, a sociedade valorizava e respeitava a professora oriunda dessa instituição[...] inclusive com remuneração significativa.

Por este argumento podemos perceber que no Rio de Janeiro esta fase de ouro da profissão docente aconteceu quando a feminização do magistério já estava consagrada, em uma época que profissão de professora era uma das poucas opções para o universo feminino, com emprego garantido ao formar-se na rede pública de ensino e com uma remuneração significativa. Além disso, ao analisar os periódicos da instituição, a autora percebe que as alunas têm a representação de que somente a mulher tem condições de conduzir a educação da criança com eficiência, pois o instinto materno manifestaria-se na escola e a sua doçura e meiguice poderia facilitar o aprendizado das crianças (MARTINS, 1996: 159; 179). No entanto, estes anos dourados não representaram a realidade de todos os Estados (onde a realidade era/é bem diferente), mas este discurso possivelmente contagiou o país, pois provinha de uma instituição paradigma para o Brasil.

Em 1961 é publicada a $1^{a}$ LDB (Lei de Diretrizes e Bases n. ${ }^{\circ} 4.024 / 1961$ ), que não trouxe soluções inovadoras para o ensino normal (apenas deu equivalência às modalidades de ensino médio) e conservou as grandes linhas da organização anterior (descentralização e flexibilização) ${ }^{83}$. As mudanças são introduzidas com o golpe militar (de 1964), onde a "visão tecnicista da escola e da formação docente" $" 84$ passa a embasar a educação e acentuar a divisão do trabalho pedagógico (em 1969 os "especialistas" passam formar-se nos cursos de Pedagogia) (TANURI, 2000: 78-79).

A LDB (Lei 5.692/71), que institui a profissionalização obrigatória do $2 .^{\circ}$ grau $^{85}$, representa um golpe na formação docente ${ }^{86}$, pois a escola normal dilui-se numa das muitas habilitações profissionais do ensino de segundo grau, a chamada Habilitação Específica para o Magistério - HEM (para ensino de $1 .^{\mathrm{a}}$ a $4 .^{\mathrm{a}}$ série o mínimo exigido era a habilitação específica de $2 .^{\circ}$ grau realizada no mínimo em 3 séries $^{87}$, admitindo-se diferenças locais ${ }^{88}$ ) (TANURI, 2000: 80-82).

Aponta-se uma descaracterização do curso $^{89}$, uma queda das matrículas e do prestígio social do curso (junto com uma desvalorização da profissão e a deterioração das condições de trabalho e remuneração do professor/a que seguiram o processo de expansão do ensino de primeiro grau), aumenta a sua concentração em classes noturnas, reduz-se o número de disciplinas pedagógicas, desarticula-se os conteúdos, dicotomiza-se teoria/prática (núcleo comum/parte profissionalizante), há também uma inadequação dos docentes ao curso (inexperientes no ensino de $1 .^{\circ}$ grau) e problemas na realização dos estágios (cumpridos apenas formalmente e/ou restringidos à observação) (MARTINS, 1996; TANURI, 2000). Antes a escola normal era acusada de hipertrofiar os aspectos específicos, depois de 1971 passou a ser considerada uma habilitação em quase tudo incompetente: fraca em conteúdo científico, não forma o/a professor/a nem para ensinar a ler, escrever e calcular (TANURI, 2000: $80-82)^{90}$. 
A partir dos anos 80 passa-se a questionar o tecnicismo do curso de Pedagogia e, conseqüentemente, discute-se a sua função. Há várias posições sobre esta função, mas a que se consolida é a de que "a docência constitui a base da identidade profissional de todo profissional da educação", portanto o curso de Pedagogia deveria se encarregar da formação para a docência primária (nos anos iniciais da escolaridade) e da formação unitária do pedagogo. Desta forma, a graduação de Pedagogia passa a ser reformulada visando também à preparação do/a professor/a primário/a em nível superior ${ }^{91}$ (tarefa que vinha desempenhando sem estar devidamente instrumentada ${ }^{92}$ ), pois (TANURI, 2000: 80-84).

Todavia, os esforços não foram suficientes ${ }^{93}$ para a formação do professor. A falta de políticas de formação foi acompanhada de ausência de ações governamentais adequadas à carreira e à remuneração do professor, o que acabava por se refletir na desvalorização social da profissão docente, com conseqüências drásticas para a qualidade do ensino em todos os níveis. Neste contexto, em 1996 a LDB (Lei 9.394/96, art 62) estabelece que os professores/as da educação básica (até o ensino médio) serão formados em nível superior ${ }^{94}$, em licenciaturas plenas, em universidades e "institutos superiores de educação" (ISEs).

Insere-se uma nova instituição no panorama educacional ${ }^{95} \mathrm{e}$, ao mesmo tempo, parecia que se desconsiderava a trajetória recente dos cursos de Pedagogia, uma superposição de cursos que causou grande polêmica ${ }^{96}$; para haver algum consenso e progressos neste debate é preciso, de acordo com a autora, que não haja a desmobilização da experiência acumulada tanto pelos cursos de Pedagogia existentes nem da experiência da imensa rede pública de cursos médios de formação (as antigas Escolas Normais) que podem ser capitalizados e aproveitados (TANURI, 2000: 85-86).

Presentemente percebem-se pequenas alterações na porcentagem de professoras no ensino primário, Campos (2002, p. 12) nos aponta um sensível declínio nos tempos atuais, o que pode provir de diferentes fatores (alto desemprego, que tende a tornar mais atrativa a atividade docente pela segurança que proporciona, aumentos de salário principalmente em pequenos municípios do interior do Norte e do Nordeste, devido à complementação dada pelo governo federal) (ver Tabela 5). Também verificamos um aumento de homens nos cursos de formação de professores, mas este ainda é baixo, os cursos voltados ao magistério (não só o primário) continuam altamente feminizados.

Tabela 5 - Número de Professores/as Primários no Brasil

\begin{tabular}{|c|c|c|c|}
\hline Período & N. ${ }^{\circ}$ de Professores & N. ${ }^{\circ}$ de Professoras & $\%$ de Professoras \\
\hline 1771 & 17 & 0 & 0,0 \\
\hline 1872 - DF/RJ & 49 & 38 & 43,6 \\
\hline 1884 - DF/RJ & 90 & 107 & 54,3 \\
\hline 1907 - DF/RJ & 29 & 652 & 95,7 \\
\hline 1909 - DF/RJ & 44 & 934 & 95,5 \\
\hline 1910 - DF/RJ & 43 & 1.015 & 95,9 \\
\hline 1911 - DF/RJ & 63 & 1.095 & 94,5 \\
\hline 1912 - DF/RJ & 60 & 1.182 & 95,1 \\
\hline 1920 & - & - & 72,5 \\
\hline 1936 & 8.678 & 56.727 & 86,7 \\
\hline 1946 & 6.502 & 86.081 & 92,9 \\
\hline 1970 & - & - & 98,8 \\
\hline 1980 & - & - & 96,2 \\
\hline 1991 & 38.854 & 554.955 & 93,4 \\
\hline 1998 & - & - & 94,0 \\
\hline 2000 & 112.337 & 1.134 .477 & 91,0 \\
\hline
\end{tabular}

Fonte: Carvalho (1986): Dado de 1771. Schueler (2005: 387): Dados de 1872 e 1884. Sousa (2006: 6475): Dados de 1936 e 1946. Brasil (1927): 1907 a 1912. Vianna (2001/2002): Dado de 1920. Bruschini \& Amado (1988: 12): 
Dados de 1970 e 1980. OIT-ILO (1991): Dado de 1991. Siniscalco (2002): Dado de 1998. IBGE Censo Demográfico: 2000 (Professores de disciplinas da educação geral de $1^{\mathrm{a}}$ a $4^{\mathrm{a}}$ séries do ensino fundamental com nível superior com total de 165.399, Professores com nível médio no ensino fundamental com total de 1.055.797, Professores leigos no ensino fundamental com total de 25.619).

\section{Correlações}

Apesar das Escolas Normais terem começado a funcionar quando o Brasil era independente de Portugal encontramos muitas correlações destas instituições nos dois países e da sua relação com a feminização do magistério. As Escolas Normais inicialmente eram instituições masculinas (tanto no seu corpo discente como docente), que não tinham muito prestígio, até porque a sua formação não era necessária para que se pudesse dar aulas.

Quando a Escola Normal passa a ser aberta para as mulheres, mesmo com muita luta feminina e também com muita resistência contra a sua entrada, em pouco tempo as mulheres ultrapassam os homens em número de discentes. Muitos discursos e ações ajudaram para que isso acontecesse: o medo da co-educação"; a defesa das "qualidades femininas" para a docência; a abertura de mais escolas normais femininas do que cursos secundários acessíveis às mulheres; o baixo salário que, associado com a necessidade de formação, torna outras áreas melhores para os homens ${ }^{98}$ (sobre a questão dos salários ver RABELO, 2010); entre outros.

Assim, a institucionalização das escolas de formação de professores/as foi um importante passo para a feminização do magistério e para o afastamento dos homens da docência. No entanto, a feminização nas Escolas Normais não se dá junto com a desvalorização docente, ao contrário, acontece ligada a uma certa valorização: tanto salarial, quanto do estatuto do/a professor/a (que passa a ser formado em uma instituição). Além disso, este é um dos primeiros locais de estudo e profissionalização feminina, o que fez com que as mulheres agarrassem e defendessem esta oportunidade, tendo em vista a falta de outras possibilidades. Esta conquista também representou a abertura progressiva de outras áreas de trabalho e estudos (secundários e superior) às mulheres ${ }^{99}$.

Atualmente, em ambos os países a formação dos docentes primários já é feita em nível superior, embora Portugal esteja mais adiantado neste processo, pois no Brasil ainda existe formação de professores em nível médio/secundário. Mesmo com várias mudanças na formação dos professores os discursos continuam fazendo com que a feminização da docência primária continue sendo realidade nos dois países (ver anexos 4 e 5).

\section{Referências}

ALMEIDA, É. P. D. Formação de professores. In: -, I. M. S. E. M. I. T. C. (Ed/Org.). Sistema de ensino em Portugal. Lisboa: Fundação Calouste Gulbenkian, 1981.

ALMEIDA, J. S. D. Mulher e educação: a paixão pelo possível. São Paulo: UNESP, 1998.

ARAÚJO, H. C. Pioneiras na educação: as professoras primárias na viragem do século: contextos, percursos e experiências, 1870-1933. Lisboa: Instituto de Inovação Educacional, 2000. 431 p p. (Memórias da educação 8)

BELTRÃO, K. I. e ALVES, J. E. D. A reversão do hiato de gênero na educação brasileira no século XX.In XIV Encontro Nacional de Estudos Populacionais, Caxambú - MG, 2004.

BENAVENTE, A. Escola, professoras e processos de mudanças. Lisboa: Livros Horizontes, 1990. 
BRASIL. Anuário estatístico do Brazil. Rio de Janeiro: Typographia da Estatistica, v.III, 1927. (1º Anno 1908-1912)

. Sinopse do censo dos profissionais do magistério da educação básica 2003. Brasília: INEP - Instituto Nacional de Estudos e Pesquisas Educacionais Anísio Teixeira, 2006.

BRUSCHINI, C. e AMADO, T. Estudos sobre mulher e educação. Cadernos de Pesquisa, v.64, p.4-13, Fevereiro 1988.

CARVALHO, R. D. História do ensino em portugal: desde a fundação da nacionalidade até o fim do regime de Salazar-Caetano. Lisboa: Fundação Calouste Gulbenkian, 1986.

GASPARI, L. T. A educação da mulher brasileira e sua postura no espaço público e privado. HISTEDBR, $\quad$ v.n. ${ }^{\circ}$ 11-Setembro, $2003 . \quad$ Disponível em: http://www.histedbr.fae.unicamp.br/art14_11.htm. Acesso em: 05/07/2007.

GIASE. Perfil do docente 2004/2005. Lisboa: Ministério da Educação de Portugal, 2006a. $2006 \mathrm{~b}$. . Séries cronológicas - alunos 1977-2006. Lisboa: Ministério da Educação de Portugal, Séries cronológicas, docentes - 1985-2005. Lisboa: Portugal - GIASE, $2006 \mathrm{c}$.

GUINOTE, P. O lugar da(o)s regentes escolares na política educativa do Estado Novo: uma proposta de releitura (anos 30-anos 50). Sísifo/ Revista de ciências da educação, v.1, p.113126, set/dez 2006.

KUHLMANN JR, M. Educando a infância brasileira In: LOPES, E. M. T., FILHO, L. M. F. e VEIGA, C. G. (Ed/Org.). 500 anos de educação no Brasil. Belo Horizonte: Autêntica editora, 2000.

KULESZA, W. A. A institucionalização da escola normal no Brasil (1870-1910). Revista brasileira de estudos pedagógicos, v.79, n.193, p.63-71, set./dez. 1998.

LEÃO, M. T. O ensino superior politécnico em Portugal: um paradigma de formação alternativo. Doutoramento. Departamento de Ciências da Educação, Universidade de Aveiro, Aveiro, 2006.

MARTINS, Â. M. S. Dos anos dourados aos anos de zinco. Tese de Doutorado em Educação. Faculdade de Educação, Universidade Federal do Rio de Janeiro (UFRJ), Rio de Janeiro, 1996.

MÓNICA, M. F. Educação e sociedade no Portugal de Salazar. Lisboa: Editora Presença/Gabinete de Investigações Sociais, 1978. (Colecção Análise Social)

NÓVOA, A. 〈〈Le>> temps des professeurs. Lisboa: Instituto Nacional de Investigação Científica, 1987. (Pedagogia 5) Um tempo de ser professor. Lisboa: [s.n.], 1988. 18 p.

Profissão: professor. reflexões históricas e sociológicas. Análise Psicológica, v.1-2-3, n.VII, p.435-456, 1989. 
Os professores: quem são? Donde vêm? Para onde vão? In: STOER, S. (Ed/Org.). Educação, Ciências Sociais e Realidade Portuguesa. Uma abordagem Pluridisciplinar. Porto: Afrontamento, 1991. p. 59-129.

Formação de professores e profissão docente. In: NÓVOA, A. (Ed/Org.). Os professores e a sua formação. Lisboa: Publicações Dom Quixote, Instituto de Inovação Educacional, 1992. p. 14-33.

NUNES, C. Formação docente no Brasil: entre avanços legais e recuos paradigmáticos. Teias: Revista da faculdade de Educação/UERJ, n.1, p.16-55, Junho 2000.

OIT-ILO. Segregat. Disponível em: http://laborsta.ilo.org/ Acesso em: 22/03/2008.

RABELO, A. A remuneração do professor é baixa ou alta? Uma contraposição de diferentes referenciais. Educação em Revista, v.26, n.01, p.57-88, abr 2010.

SANTOS, H. H. M. D. A história do instituto de educação, 2004. Disponível em: http://www.cemiiserj.xpg.com.br/. Acesso em: 12 de Setembro de 2007.

SARMENTO, M. J. Lógicas de acção nas escolas. Lisboa: Instituto de Inovação Educacional/Ministério de Educação, 2000.

SCHAFFRATH, M. D. A. S. Profissionalização do magistério feminino: uma história de emancipação e preconceitos.In $23^{a}$ Reunião Anual da Anped, 2000.

SCHUELER, A. F. D. Representações da docência na imprensa pedagógica na corte imperial (1870-1889): o exemplo da instrução pública. Educação e Pesquisa, v.31, n.3, p.379-390, set./dez. 2005.

SERRA, F. H. S. Concepções educacionais em tempos revolucionários: Uma abordagem histórico-sociológica do ensino primário e da formação de professores em Portugal no pós 25 de Abril de 1974 - Volume III. Doutoramento. Faculdade de Ciências, Universidade de Lisboa, Lisboa, 2004.

SINISCALCO, M. T. A statistical profile of the teaching profession. Geneva: International Labour Office (ILO/OIT) - UNESCO, 2002.

SOUSA, C. P. D. A escola de massas em Portugal e no Brasil nas estatísticas da Unesco: um estudo histórico-comparado (de 1946 aos anos 60).In Congresso Luso-Brasileiro de História da Educação, Uberlândia, 2006.

TANURI, L. M. História da formação de professores. Revista Brasileira de Educação, v.14, p.61-88, Mai/Jun/Jul/Ago 2000.

VIANNA, C. P. O sexo e o gênero da docência. Cadernos Pagu, v. 17/18, 2001/2002.

VILLELA, H. D. O. S. O mestre-escola e a professora. In: LOPES, E. M. T., FILHO, L. M. F. e VEIGA, C. G. (Ed/Org.). 500 anos de educação no Brasil. Belo Horizonte: Autêntica editora, 2000.

WERLE, F. O. C. Práticas de gestão e feminização do magistério. Cadernos de Pesquisa, v.35, n.126, 2005. 


\section{Notas:}

${ }^{1}$ As entrevistadas de Araújo (2000) demonstram algumas das motivação das mulheres para a escolha a escola normal: porque era um curso mais rápido do que o curso universitário (que possibilitava trabalhar e casar mais rápido); pela escassez de oportunidade de trabalho para as raparigas; porque era inteligente e gostava de ler; por ter contato com o ensino na família.

${ }^{2}$ Além da desvalorização progressiva do estatuto econômico e profissional dos professores do ensino primário e da ideologia divulgada sobre a necessidade de "vocações femininas" para o trabalho com crianças pequenas.

${ }^{3}$ Essa escola funciona até 1928 , pois D. Miguel entra no poder e a realidade escolar muda novamente: a vida dos professores e mestres é devassada para verificar as suas inclinações políticas, há perseguições e encerramento de escolas, chama-se os eclesiásticos para darem aulas (pela sua contribuição moral e isenção de cuidados domésticos) e autoriza-se em 1832 o retorno dos jesuítas (CARVALHO, 1986).

${ }^{4}$ O nome "Escola Normal" provém da França e é utilizado para designar um estabelecimento que dirige uma formação uniforme aos mestres, contribuindo à normalização (NÓVOA, 1987: 425).

${ }^{5}$ Almeida (1981) considera que desde 1835 pode dizer-se que há formação de professores em Portugal, data em que se criam escolas normais nas capitais de distrito.

${ }^{6}$ Houve reclamação porque o corte do subsídio abaixaria o já baixo número de alunos homens.

${ }^{7}$ A primeira Escola Normal de Marvila funciona de 1862 a 1869, quando forma 91 normalistas, 71 vão ser professores públicos (nesta escola cria-se também um curso noturno para adultos e biblioteca para operários). A escola fecha de 1869 a 1972 e volta a funcionar de 1872 a 1881, quando outra escola normal masculina é criada em Angra do Heroísmo (NÓVOA, 1987).

${ }^{8}$ Mas no ensino privado as mulheres já são apresentadas como maioria dos professores primários (56,8\%), 93,5\% são laicos, recebem menos do que os professores públicos (na média $38 \%$ menos) e $82,1 \%$ deles é responsável pela escola (NÓVOA, 1987).

${ }^{9}$ António da Costa (que defende a instrução em igual proporção para ambos os sexos, mas com preferência à educação feminina porque elas educariam os filhos e também deveriam ser responsáveis pela instrução primária do sexo masculino) cria em agosto de 1870 duas escolas normais femininas e torna a instrução primária obrigatória para ambos os sexos, mas fica no ministério por 2 meses. Depois vários decretos são revogados, inclusive a criação das escolas normais femininas(CARVALHO, 1986: 602).

${ }^{10}$ O Estado tornou-se dono de edifícios de ordens religiosas expulsas em 1834.

${ }^{11}$ É importante destacar que de 1882-1903 elas formam mais mulheres que homens (NÓVOA, 1987).

${ }^{12}$ Com currículo diferenciado para homens e mulheres (ARAÚJO, 2000: 106).

${ }^{13}$ Além disso, Carvalho (1986: 605) refere que a criação destas escolas só é regulamentada em 1881.

${ }^{14}$ Neste ano o governo confia também a organização do júri dos exames de admissão ao magistério primário às escolas normais.

${ }^{15}$ Atual ensino secundário, que preparava e permitia o acesso à Universidade.

${ }^{16}$ Em Lisboa. Só abre em outros lugares de Portugal em 1919.

${ }^{17}$ Para Nóvoa (1987) as Escolas Normais representaram um dos fatores profissionalização docente, outros fatores foram: o exercício da docência em tempo integral (no período pombalino a maior parte dos professores se vêm na obrigação de praticar a tempo integral); o suporte legal para o exercício da profissão (no período pombalino); a criação de associações de grupos de profissionais docentes. A profissionalização da atividade docente é apresentada como um processo que se organiza entre o fim do século XVIII e o início do século XX, relacionado com a laicização e a estatização do sistema de ensino e o desenvolvimento do projeto de escolarização, assim, a partir do fim do século XVIII a profissionalização da atividade docente se dá junto com a história da instituição escolar (pois a educação se confunde cada vez mais com o ensino na escola devido ao seu privilegiado lugar da ação educativa).

${ }^{18}$ Serra (2004) identifica que na Escola Normal Primária de Lisboa o período áureo vai de1918 a 1935, tendo professores ilustres, republicanos, renovadores e progressistas.

${ }^{19}$ Quem se forma teria 11 anos de ensino, teria acesso ao ensino superior e poderia aspirar a outras categorias como o magistério na escola normal.

${ }^{20}$ Almeida (1981) refere que a lei de 29 de Março de 1911 e a Lei de 7 de Junho de 1914 acentuam a importância das escolas normais.

${ }^{21}$ Mas ele destaca que a compreensão histórica exige um tempo humano e não só períodos chaves.

${ }^{22}$ As associações docentes também são alvo de medidas radicais do Estado Novo: em 1928 elas são abolidas (e são presos os dirigentes da União do Professorado Primário Oficial). Em 1930 permite-se que os professores constituam associações, mas veda às associações de discutirem atos dos seus superiores e de ocuparem-se de assuntos estranhos ao objetivo social. Em 1932 os professores passam a ser repreendidos se discutirem atos dos seus superiores (Carvalho, 1986).

${ }^{23}$ Que formavam professores pós-primários. 
${ }^{24}$ Justifica-se que era necessário reduzir despesas, mas que o ato foi repensado para o bem da cultura.

${ }^{25}$ Realiza-se um exame de admissão, reduz-se da idade mínima de 15 para 14 anos e a escolaridade de $1 .^{\circ}$ ciclo dos Liceus - ou o equivalente nas Escolas Técnicas - para o ingresso.

${ }^{26}$ Em Outubro de 1926 cria-se 12 escolas infantis, mas não tinha professores, os professores primários que não faziam falta poderiam ir para ela, ou seja, o ensino infantil continuou sem existência real (CARVALHO, 1986: 733).

${ }^{27}$ Em 1930 todos os professores deveriam se submeter aos Exames de Estado para ter habilitação plena, era uma arma, até os professores competentes e inteligentes não ficavam seguros de ter boa nota (MÓNICA, 1978: 207). Esse exame só foi extinto em 1974.

${ }^{28}$ Os postos são extintos só em 1980, apesar de ter a sua progressiva substituição decretada em 1973.

${ }^{29}$ Os regentes são nomeados a partir de Novembro de 1931.

${ }^{30}$ Os professores contestaram tal atitude sentidos feridos na dignidade da sua profissão e economicamente

prejudicados, pois alguns não conseguiam emprego porque os regentes ocupavam os postos (CARVALHO, 1986).

Alguns demarcam que passa a ser necessário complementar a remuneração com outras atividades, o que deteriorava a qualidade (NÓVOA, 1991: 112).

${ }^{31}$ Para o autor a figura do regente não é necessariamente um sinal da desvalorização da educação, nem esta foi ocasionada pela feminização e docilidade do professorado, até porque alguns regentes estudavam e tinham acima da $4 .^{\mathrm{a}}$ classe e a docilidade não é comprovada.

${ }^{32}$ Além disso, o autor compara esta política com a criação das Escolas Móveis na República, que pagava a qualquer um que alfabetizasse alguém, independente da formação.

${ }^{33}$ Atraía, de início, mulheres mais velhas (acima de 30 e 40 anos), depois mais jovens (chega a ter de 16 a 17 anos, mas a maioria tem menos de 30 anos, diferente dos professores) prioritariamente solteiras (que possivelmente pediam exoneração quando casavam - porque o casamento não foi autorizado, as condições familiares não permitiriam o trabalho, ou não necessitariam dele) (GUINOTE, 2006).

${ }^{34}$ Há incentivos para que se formem e muitos diplomam-se.

${ }^{35}$ Entre 1940-1960 centenas de escolas primárias fecharam por falta de professor (MÓNICA, 1978: 207).

36 "O Plano dos Centenários" (centenários porque em 1940 comemorava-se oitocentos anos de independência nacional e de trezentos anos do fim do domínio espanhol) previa a construção de 12.500 salas de aula no prazo de 10 anos. Em 1951 1/4 das escolas foram construídas com mais da metade do dinheiro gasto, três décadas depois muitas escolas não tinham sido construídas (MÓNICA, 1978: 171).

${ }^{37}$ Extingue-se, inclusive, o Exame de Estado em finais de 1973-74 (que era uma prova final do período de estágio pedagógico, após aprovado era possível considerar-se profissionalizado e/ou efetivado) (ALMEIDA, 1981).

${ }^{38}$ Em 25 de Abril de 1974 aconteceu um levantamento militar que derrubou, num só dia, o regime político do Estado Novo, sem grande resistência do governo, que cedeu perante o movimento militar, apoiado pela larga maioria da população. O levantamento foi conduzido por capitães da hierarquia militar. Considera-se, em termos gerais, que esta revolução devolveu a liberdade ao povo português (denominando-se "Dia da Liberdade" o feriado instituído em Portugal para comemorar a revolução no dia 25 do mês de Abril, este levante também recebe as designações " 25 de Abril", ou "Revolução dos Cravos").

${ }^{39} \mathrm{O}$ recrutamento massivo de professores num tempo curto também desencadeia fenômenos de desprofissionalização do professorado (NÓVOA, 1992: 20).

${ }^{40}$ Um despacho de 30 de Outubro de 1974 introduz algumas mudanças (como a supressão da disciplina educação feminina, o fato de não ser mais obrigatório o diretor dar a disciplina Pedagogia, entre outras), outro, de 31 de Julho de 1975, reformula a estrutura curricular (tornando-a mais interdisciplinar) e aumenta o curso para 3 anos letivos (era de 2 anos) e retoma a formação do magistério infantil (extinta em 1937). Em 1976, 1977, 1978 há novas mudanças curriculares (BENAVENTE, 1990; SERRA, 2004).

${ }^{41}$ O regime de "experiências pedagógicas", autorizado em um comunicado de 16 de Novembro de 1974, foi solicitado pelos novos responsáveis pelas escolas de magistério que se preocupavam com os entraves burocráticos iniciais que impediam a renovação das mesmas, assim este período é marcado por ser revolucionário; mas o despacho $n^{\circ} 61 / 76$ de 29 de Julho suspende o regime de "experiência pedagógica" (aponta-se essa e outras medidas como uma investida da direita contra o "terror comunista" ou a "recuperação capitalista", um refluxo da revolução, pois a direita não via com bons olhos a "calmaria" do tempo da "experiência pedagógica") (SERRA, 2004). Neste período de "experiência pedagógica”, de acordo com Benavente (1990: 36-37), aconteceram várias experiências interessantes.

${ }^{42}$ Também explicado e referido por Leão (2006), que mostra que a lei n. ${ }^{\circ} 61 / 78$ integra estas escolas no ensino superior o que correspondia a um natural desejo de melhorar a formação concedida, fica responsável também por formação em serviço, atualizações e aperfeiçoamento. Esta lei também cria os CIFOP's (Centros Integrados de Formação de Professores) e já menciona a reconversão das escolas normais de educadores de infância e das escolas do magistério primário em escolas superiores de educação até o início do ano letivo de 1979/80, o que não acontece neste ano.

${ }^{43}$ A partir deste período, institucionalizam-se práticas integradas de formação de professores (em cursos de licenciatura em 4 anos) nos ramos educacionais das faculdades de ciências, ou em universidades novas (Universidade do Minho e de Aveiro e no então Instituto Universitário dos Açores). Havia, assim, clivagens na formação de professores e no seu 
estatuto: no ensino médio e nas universidades. As ESEs surgem neste contexto para, em uma mesma instituição, dar formação integrada, especialização homogênea, conjugar formação inicial e contínua, integrar a comunidade. ${ }^{44}$ Ver Decretos-Lei n. ${ }^{\circ} 101 / 86$, n. $^{\circ}$ 178/89.

${ }^{45}$ As Escolas do Magistério Primário passam a ser progressivamente extintas a partir de 1986, encerrando-as efetivamente em 1987-1988 e 1988-1989.

${ }^{46} \mathrm{Na}$ admissão, nos conteúdos, no tempo de formação e na menor exigência intelectual e científica.

${ }^{47}$ A degradação do estatuto profissional e econômico dos professores durante os anos 80 favoreceu a ambiência reformadora inspirada por tendências internacionais, mas, apesar de algumas melhorias significativas, estas foram incapazes de conceber uma "nova profissionalidade". Os saberes são impostos do exterior o que acentua a subordinação da profissão docente, instaura-se de novos controles sobre a profissão docente, mas subtis, prolongados através de uma tutela científico-curricular: "A política reformadora tem aprofundado o fosso que separa os actores dos decisores" (NÓVOA, 1992: 22).

${ }^{48}$ Mas esta formação contínua não é concebida na lógica do desenvolvimento profissional dos professores e organizacional das escolas. Nóvoa (1992: 23) demarca que "É preciso reconhecer as deficiências científicas e a pobreza conceptual dos programas actuais de formação de professores. E situar a nossa reflexão para além das clivagens tradicionais (científico versus pedagógico, disciplinas teóricas versus disciplinas metodológicas, etc.), sugerindo novas maneiras de pensar a problemática da formação de professores". Necessita-se de redes de (auto)formação, centradas nas dimensões coletivas, onde a troca de experiências e a partilha de saberes façam com que o professor seja tanto formador como formando.

${ }^{49}$ Como aponta Sarmento (2000: 213) esta feminização não encontra paralelo em nenhum outro país da OCDE.

${ }^{50}$ Iniciativas que antecedem as de formação, mas permanecem concomitantemente com estas.

${ }^{51}$ Denuncia-se porém, em 1893 que muitas não foram criadas, a maioria estava em estado deplorável, com professores ignorantes (homens), onde o subsídio literário não bastava para pagar o professorado.

${ }^{52}$ Forma exclusivamente prática, preocupando em ensinar as primeiras letras e preparar/instruir docentes, no domínio do método; seria depois retomada com o estabelecimento de "professores adjuntos".

${ }^{53}$ O Governo Central ocuparia-se do ensino na capital do Império (RJ) e do superior em todo o país, e as províncias seriam responsáveis pela instrução primária e secundária nos seus territórios. Assim, as escolas normais no Brasil fizeram parte dos sistemas provinciais desde a sua criação (TANURI, 2000: 63).

${ }^{54}$ Era para cidadãos, mas só os homens eram considerados cidadãos (MARTINS, 1996; GASPARI, 2003)

${ }^{55}$ Em 1840 ela havia formado apenas 14 alunos, dos quais 11 se dedicaram ao magistério.

${ }^{56}$ Schueler (2005) mostra que os professores na corte entre nas décadas de 1870-80 eram geralmente provenientes de classes pobres, que precisavam do salário para sobreviver, e tinham representações sobre si mesmos de pobreza, austeridade, sacrifícios, sacerdócio e missão. Mas, através da imprensa educacional, puderam mostrar-se como categoria profissional que não era passiva às reformas do governo nem alheia a formulações próprias.

${ }^{57}$ Auxiliares que aprendiam o exercício a profissão docente na prática. Esta modalidade, de acordo com Schueler (2005: 384), fazia com que estes professores (que em geral eram pobres, recebiam pouco e dependiam do salário), não tivessem condições de aprimorar os estudos e freqüentar uma Escola Normal.

${ }^{58}$ Os Liceus formavam as elites masculinas e influenciaram a implementação das escolas Normais que tinham caráter profissional. A baixa remuneração, a não necessidade de formação, as poucas vagas existentes e o reduzido prestígio social, fizeram com que poucos elementos da clientela dos Liceus, essencialmente pertencente à elite local, seguissem por esse caminho (KULESZA, 1998: 66). Além dos estudos secundários serem masculinos, Beltrão \& Alves (2004) destacam que eram caros e só eles habilitavam para as faculdades, os cursos normais não davam esse acesso, mais um dos motivos para ). Os cursos normais não habilitavam as mulheres. O que inviabilizou a sua entrada.

${ }^{59}$ Adicionando uma cadeira de Pedagogia ao currículo, aligeirando a parte de formação geral e reservando a prática profissional para ser exercida junto a alguma escola primária pública.

${ }^{60}$ Kulesza (1998: 69) também destaca que uma das modalidades de criação das escolas normais foi a extensão da escolarização de órfãos entregues a instituições regidas por ordens religiosas, com clientela predominantemente feminina e viés prático das alunas ajudarem na educação das órfãs menores.

${ }^{61}$ Dada a possibilidade remota de um bom casamento, pois a pobreza da mulher continua sendo demonstrada, nos romances da época, como um empecilho ao casamento; assim, apesar de incorporar a idéia da união amorosa entre duas pessoas, as bases econômicas do casamento continuam a influenciar a mentalidade (ALMEIDA, 1998).

${ }^{62}$ Kulesza (1998: 69-70) afirma que na maioria dos Estados, a feminização do magistério foi muito mais acentuada em detrimento da sua profissionalização, ao contrário de São Paulo (onde ainda se formava cerca de um terço de professores homens no início do século).

${ }^{63}$ Martins (1996: 80) destaca que a partir de 1870 a Escola Normal passou a ser definida como "lócus" para formar professores.

${ }^{64}$ A Reforma Leôncio de Carvalho de 1879 é um exemplo disso, pois fixava a duração do curso não em anos, mas em séries de matérias nas quais os alunos se submeteriam a exames (TANURI, 2000: 67). 
${ }^{65}$ Estas professoras iam dar aula nas poucas vagas para dar aula a meninas ou como preceptoras. Para as moças de alto poder aquisitivo a freqüência às escolas normais era para ser esposa agradável e mãe dedicada (Bruschini \& Amado, 1988, p. 5).

${ }^{66}$ Até mesmo o termo "normalista" passa a sugerir sempre moças. Kulesza (1998: 68) no seu estudo sobre as escolas normais de 1870-1910 só encontrou uma utilização deste termo no masculino. Almeida (1998: 154) refere que este termo é associado ao feminino nos anos 1940, inclusive com desdém.

${ }^{67}$ Kuhlmann Jr (2000: 479) cita que no Rio de Janeiro, o Decreto Municipal 377, de 23/3/1897, chegou a prever que, gradualmente, o ensino primário fosse exclusivamente feminino, aí incluídas as classes de jardim-de-infância.

${ }^{68}$ Pelo menos em tese, elas adquiriram o direito à educação.

${ }^{69}$ O Governador Gustavo Richard (1906-1909) preocupava-se com a alta procura das mulheres por este curso e pelo magistério e propõe que os moços candidatos a normalistas de outras cidades fossem ser liberados dos exames de admissão para a Escola Normal (SCHAFFRATH, 2000).

${ }^{70}$ A primeira República era um Estado Oligárquico (visando os interesses dos grupos dominantes das regiões produtoras de café) que não trouxe alterações significativas para a instrução pública e representava mais a continuidade do movimento de idéias que se iniciara nos últimos anos do Império, inclusive na criação das Escolas Normais (KULESZA, 1998; TANURI, 2000).

${ }^{71}$ É após a implantação do regime republicano, em fins do século XIX, que o magistério também passou a receber mais mulheres que homens (ALMEIDA, 1998).

${ }^{72}$ O modelo de São Paulo passa a ser paradigma para vários Estados, a Reforma de Caetano de Campos em 1890 amplia a parte propedêutica da escola normal em 4 anos (exigindo cultura enciclopédia para ingresso), introduz as escolas anexas e as idéias de Pestalozzi. O ensino primário passa a ter 8 anos, dividido em elementar e complementar (este último acaba servindo como acesso ao ensino normal e como escola normal primária, criando um dualismo nas escolas de formação, abolido em São Paulo em 1920).

${ }^{73}$ Modelo baseado na Reforma Fernando de Azevedo de 1928 no DF/RJ. Porém, critica-se a divisão entre cultura geral e de cultura profissional, pois falhava nos dois objetivos.

${ }^{74}$ Em Minas Gerais havia a Escola Normal de 1. ${ }^{\circ}$ Grau (5 anos de estudos), Escola Normal de $2^{\circ}$ Grau (7 anos), Escola Normal Rural ( 2 anos), Aperfeiçoamento Pedagógico ( 2 anos), entre outras. Em 1930 havia 21 escolas em Minas Gerais, 6 de $2^{\circ}$ grau, com 3892 alunos (antes havia 2 escolas com só 222 alunos). Na década de 1930 e 1940 a preocupação com os valores rurais e fixação do homem no campo, motiva a criação da Escola Normal rural em outros Estados. Também se expande as escolas normais de iniciativa privada e municipal (TANURI, 2000: 71-73).

${ }^{75}$ Baseado na Reforma realizada por Anísio Teixeira no Distrito Federal/Rio de Janeiro em 1932.

${ }^{76}$ No Rio de Janeiro, por exemplo, em 1943 o Instituto de Educação torna-se um externato limitado ao sexo feminino (com escolas anexas, vários cursos e com a formação de professores no nível secundário) (MARTINS, 1996: 145; 149). Só em 1962 (de acordo com informações obtidas junto ao Centro de Memória Institucional do Instituto) os homens podem voltar a candidatar-se a esta escola.

${ }^{77}$ No interior do Brasil, mas especificamente de São Paulo, Almeida (1998: 187-188) atenta que as escolas não davam conta da escolarização de todas as jovens e muitos pais sequer pensavam no seu deslocamento para estudo em outros locais. A opção de estudo encontrada era o colégio religioso (católico, com educação separada por gênero, ao contrário da maioria das escolas estaduais que adotavam o regime co-educativo) que passou a oferecer também o Curso Normal para as meninas. Muitas cidades do interior não possuíam uma Escola Normal oficial e muitas vezes as moças só podiam freqüentar escolas particulares que ofereciam o curso nas cidades do interior, o que nem sempre acontecia por causa das dificuldades da família em arcar com as despesas de uma escola paga, assim como a ida para outra cidade seria inviável por conta dos costumes familiares.

${ }^{78}$ Poucos meses depois da aprovação desta lei, a Constituição promulgada em 1946 retoma a orientação descentralista.

${ }^{79}$ A lei esclarece que os dois níveis são julgados necessários na formação docente de grau primário, em virtude das diferenças de ordem econômica e cultural existentes entre as várias regiões do país.

${ }^{80}$ Para habilitar diretores, orientadores e inspetores.

${ }^{81}$ São Paulo e Bahia tinham sistemas diferentes; Alagoas, São Paulo, Sergipe, Amazonas e o Distrito Federal (RJ) não mantiveram a dualidade de instituições formadoras.

${ }^{82}$ Em 1951 havia 546 escolas normais de primeiro e segundo ciclos (168 eram escolas públicas estaduais, sendo 378 particulares ou municipais), mas 258 estavam concentradas em apenas dois estados (SP e MG, SP em 1920 tinha só 10 escolas normais públicas, e em 1956 aumentou para 272, sendo 147 particulares e 17 municipais). Alguns Estados só tinham 2 escolas (MA, SE, RN). Quanto às matrículas em todo o país, em 1945 registrou-se 27.148, mas em 1955 cresceram para 70.628, em 1965 para 220.272, atingindo 347.873 em 1970. Contudo, o Censo Escolar de 1964 iria revelar que ainda não atendiam às necessidades, pois apenas $161.996(56 \%)$ dos 289.865 professores primários em regência de classe tinham realizado curso de formação profissional (concentrados mais em certos Estados), problema ainda agravado pela decisão de proibir o ingresso de maiores de 25 anos aos dois tipos de escolas normais, impedindo a qualificação de boa parte do numeroso professorado leigo (TANURI, 2000: 77).

${ }^{83}$ A maioria dos estados conservou o sistema dual, com escolas normais de nível ginasial e colegial (com exceção dos Estados SE, ES, RJ, Guanabara, SP e DF/Brasília só com escolas de grau médio). 
${ }^{84}$ Ou seja, a "operacionalização" dos objetivos, o "planejamento, coordenação e o controle" das atividades, os "métodos e técnicas" de avaliação. A escola deveria ser "eficiente e produtiva" preparando para o trabalho e visando o desenvolvimento econômico do país.

${ }^{85}$ Equivalente no Brasil atualmente ao ensino médio e em Portugal ao ensino secundário.

${ }^{86}$ Martins (1996: 180; 186) descreve que a partir da década de 1970 a profissão de professor começou a descer uma "escada simbólica" que o levou aos seus "anos de zinco" (quando a profissão desvaloriza-se). Com baixa origem social, desprestigio social da carreira docente, salários aviltantes, instalações escolares precárias, escasso material didático, a categoria "operário da educação" vem substituindo o tão sonhado "profissional da educação.

${ }^{87}$ Assim, abole-se a escola normal de nível ginasial. Para ensinar de $5^{\mathrm{a}}$ a $6^{\mathrm{a}}$ série admite-se os estudos adicionais de 1 ano nas escolas normais, para as outras séries só o ensino superior (Tanuri, 2000, p. 81).

${ }^{88}$ Em São Paulo até 1987, por exemplo, divide-se em habilitações pré-escolar, $1^{\mathrm{a}}$ e $2^{\mathrm{a}}$ série, $3^{\mathrm{a}}$ e $4^{\mathrm{a}}$.

${ }^{89}$ Contraditoriamente, de acordo com Clarice Nunes (2000: 23), esta lei apresenta um projeto audacioso, pois propõe a formação do professor primário em nível universitário em cursos de licenciatura plena, mas define as condições mínimas, que na realidade foram as que aconteceram, além disso definiu o salário pela formação e não pelo nível de ensino, mas na prática continuou ganhando menos.

${ }^{90}$ Em 1982, a percepção dessa situação estimula a criação pelo MEC dos Centros de Formação e Aperfeiçoamento do Magistério (CEFAM), mas a descontinuidade administrativa dificultou a implementação contínua/efetiva de programas para a melhoria da formação docente (TANURI, 2000: 83).

${ }^{91}$ Aconteceram algumas tentativas anteriores de formar professores primários em nível superior. Em 1935 a Escola de Professores é incorporada pela Universidade do Distrito Federal (em 1939, com sua extinção, volta a ser integrada ao Instituto de Educação-RJ). Em 1934 também é incorporada em São Paulo à USP e desvinculada em 1938. Em 1959 a reforma de Goiás teve uma iniciativa original/pioneira: cria um curso normal superior (com 2 séries) para formar professores primários no Instituto de Educação, com currículo parecido ao dos cursos de Pedagogia, funcionou por dois anos, pois declara-se a sua criação inconstitucional (a formação de professores em nível superior era de exclusiva competência das Faculdades de Filosofia) (TANURI, 2000: 73-77).

${ }^{92}$ Em 1939 surge o curso de Pedagogia (primeiro na Faculdade Nacional de Filosofia da Universidade do Brasil) com função de formar bacharéis (para atuar como técnicos de educação) e licenciados (destinados à docência nos cursos normais). Iniciava-se um esquema de licenciatura que passou a ser conhecido como " $3+1$ ", três anos dedicados ao "conteúdo" e um ano de "didática", para a formação do professor. Em 1968 (Lei 5.540/68) o curso de Pedagogia passa a ser fracionado em habilitações técnicas, para formação de especialistas. A partir de 1969 (com o Parecer CFE 252/69) passou a ter a habilitação "magistério para o ensino de $2^{\circ}$ grau", que passou a visar também ao preparo dos professores para as séries iniciais (chegou a criar-se habilitações específicas para esse fim) (TANURI, 2000: 74; 80).

${ }^{93}$ Em 1994 existiam apenas 337 cursos de Pedagogia em todo o país (239 de iniciativa particular, 35 federais, 35 estaduais e 28 municipais), com grande concentração na região sudeste, onde se localizavam 197 cursos (165 particulares). Em 1996 existiam 5.276 estabelecimentos de ensino médio com habilitações para o magistério (3.420 em escolas estaduais, 1.152 em escolas particulares, 761 em municipais e 3 federais) (TANURI, 2000: 85).

${ }^{94}$ A lei admite como formação mínima a oferecida em nível médio, nos cursos normais. Entretanto, estipula nas disposições transitórias um prazo de apenas dez anos para essa formação acabar. Porém, dois pareceres $\left(\mathrm{CNE} / \mathrm{CEB} \mathrm{n}^{\circ}\right.$ 1/2003 e CNE/CEB nº 3/2003) do Conselho Nacional de Educação afirmam a validade da formação docente de nível médio. O que confirma a suposição de Tanuri (2000: 85) que em muitos lugares do país, dada a necessidade, tais formações poderão subsistir ainda por algum tempo.

${ }^{95}$ Provavelmente por inspiração dos Institutos Universitários de Formação de Mestres franceses.

${ }^{96}$ Alguns temem um nivelamento por baixo nos ISE em face da ênfase prática, desvinculada da pesquisa. Outros defendem este curso, até porque os institutos chegam em lugares que a Universidade não alcança. Há até quem considere que o pedagogo deve ser só o especialista.

${ }^{97}$ Temia-se o homem ensinando a meninas, consequentemente passa-se a abrir mais escolas normais femininas, pois precisava-se de professoras para dar aulas às meninas nas escolas primárias e as mulheres passam também a ensinar em turmas mistas.

${ }^{98}$ Principalmente nos grandes centros urbanos do Brasil, onde a taxa de feminização até hoje é maior (BRASIL, 2006).

${ }^{99}$ De acordo com Lopes (2001, p. 264-265) a entrada das mulheres na esfera pública interliga-se a transformação das formas de patriarcado (da "forma privada" que excluía as mulheres da esfera pública a "formas públicas" onde as mulheres estão na arena pública, mas em posição subordinada).

Recebido em janeiro de 2012

Aprovado em maio de 2012 